\title{
Assessing the Undergraduates' Use of the University Library
}

\begin{abstract}
An academic library deserves to be appraised in terms of the use made of it by undergraduates. In an effort to apply these terms four studies were conducted in a specific library to determine what students did there and to analyze their long-term withdrawal of books. Details are given on the purposes behind student visits to libraries, and statistics are enumerated on student withdrawals by class and by sex. The library appears to be a greater potential educational force than is being realized.
\end{abstract}

\begin{abstract}
A A THOUCH THE UNVERSTTY LIBRARY is regarded consensually as a potent educational force, its strength is more often than not described in terms of its physical facilities, the extent of its collections, or even its budget. Important and limiting though these are to the library's effectiveness, a listing of the "bricks and mortar" or perhaps the "linen and vellum" does not provide a measure of the library's effectiveness as an instrument of education. Such measures can be obtained only by assessing the extent to which students use the library and the extent to which such use relates to aca-
\end{abstract}

Mr. Lane is Professor of Psychology and Chairman of the University Impact Study in the University of Delaware. Studies such as are summarized in this report cannot be conducted without the full cooperation of the library staff. The author is deeply indebted to the staff members of the libraries at the University of Delaware for their interest and cooperation. Special thanks should be given to Richard D. Quick, who at the time of these studies was Assistant to the Director of Libraries at the University of Delaware, and to Alda Beach, who as a member of the Impact Study staff, had much to do with the analysis of the data. demic growth. These assessments are not easy. They are time-consuming and expensive, and they cannot be achieved with complete objectivity. The library may be outwardly a quiet place, but it is not static, nor are its users. They cannot be manipulated and controlled in the manner required by objective research, and it is well known that the person who knows that he is being studied will often alter his behavior to meet the expectations of the researcher.

Yet attempts to assess the effectiveness of such a facility as a library can produce worthwhile results and provide information useful to administrators, students, and faculty. The information gained through such attempts can certainly be more meaningful to an accreditation team than the traditional descriptive and "counting" reports which have been and are customary. With such thoughts in mind, the University of Delaware has been attempting in recent years to devise ways of discovering the impact which its facilities and programs have on its undergraduates. Among the facilities studied was the university library.

In order to measure the extent to 
which the university library was used by students and faculty, four studies were designed and carried out. It was the purpose of the first two studies to determine what students were doing when they were in the library. ${ }^{1}$ In May 1962 a relatively brief questionnaire was distributed by library personnel sixteen times during a five-day period at three different hours each day, to all students who were in the library. The questionnaire asked several detailed questions concerning the materials the students were using at the time of the survey and those they had used during the preceding week. Questions were answered by a single word or a check mark. The questionnaire was unsigned, and students were asked to return it to the main desk of the library when they left, and not to fill out a questionnaire more than once.

From an undergraduate population which was then just under three thousand, slightly fewer than seven hundred responses were obtained during the week of the survey. In proportion to the total number of students in their class, more seniors (approximately 28 per cent) were using the library than members of any other class. Sophomores were next in frequency, and freshmen were fewest (approximately 18 per cent).

At the time of the survey, there were five undergraduate schools. An analysis of the sample by school and class showed that fewer than 30 per cent of the total number of students in any school were using the library facilities. Of the five schools, that having the highest percentage of its students in the library was the school of education; students in the school of agriculture were represented least. It should be noted, however, that the school of agriculture has a separate library, and the department of chemistry (in the school of arts

\footnotetext{
${ }^{1}$ Gorham Lane, "Report No. 1 on the Use of the University Library: Library Questionnaire Study," University of Delaware, September 19, 1962, p. 7.
}

and science) also has a separate library. In all schools, with the exception of home economics, the number of seniors was greater than the number of freshmen; sophomores were also much in evidence.

Since university libraries are often used not just as a source of library materials but also as a place where students study their own books and notes, an analysis was made of the materials the students were using at the time of the survey. More than half of the freshmen were using only their own books, but the number of students using the library as a place in which to study their own books decreased steadily from the freshman through the senior class. Conversely, the number of students using only library books increased. Somewhat more than a third of the students in all classes were using both their own and library books. Reserved books were being used by more people than any other library materials, with reference books next in frequency. Microfilm and recordings were being used least, and an analysis by class showed that with the exception of recordings, seniors were the most numerous users of all types of library materials. Seniors, more than any other group, were using the library for "course related work" or "research," and fewer of them were using the library for "regularly assigned" work. The results also showed that although seniors were the most numerous and heaviest users of library facilities, they did not necessarily spend as much time in the library as members of other classes.

The first study was conducted toward the end of the second semester, shortly before the beginning of final examinations. The second study, which used the same questionnaire and techniques, was conducted during a week in the middle of the first semester. ${ }^{2}$ In this study, data

${ }^{2}$ Gorham Lane, "Report No. 5 on The Use of the University Library: Library Questionnaire Study (Supplementary Report)." University of Delaware, February 21,1963, p. 4. 
were collected not only from the main library but also from the libraries located in the department of chemistry and the school of agriculture. More students were in the libraries at the time of the second survey but, in general, results were similar to those of the first. Library use increased progressively from the freshman through the senior year, and again it was shown that seniors do not spend more hours in the library than members of other classes, but that they are more frequently found there and are more likely to be using library materials. In the main library reserved and reference books again were found to be in use more than any other materials. In the agriculture library, periodicals were being used most heavily. In this survey it was the school of home economics which had the largest percentage of its students in the library.

The nature of the work being done by students was different in the two surveys. In the first, seniors, as compared with members of other classes, were more likely to be engaged in "course related" work or "research," rather than in "assigned" work. In the second survey, there were no differences in the percentage of students from each class devoting time to these three activities. This finding might reflect the commonly observed and deplored but ubiquitous tendency for students to allow work on term papers and research projects to accumulate until the end of the semester. The findings also may reflect the assignmentgiving habits of the faculty.

In both surveys the number of students using the library for recreational reading was small. The library seems to be regarded as a place for study and required reading, and the use of the library for this purpose increases year by year from the freshman through the senior years. This is attested to not only by the larger number of students who use the library in each of the four years, but by the increasing number of upperclass- men who make use of library materials rather than their own books. In the more recent survey, approximately 4 per cent of the freshmen in the library were using library materials only; the comparable figure for seniors was 19 per cent. The percentage of freshmen using periodicals was 3.9 ; for seniors it was more than 8.

The third study investigated the longterm withdrawal of books from the general collection by undergraduates. ${ }^{3}$ Starting in the fall of 1961, for a period of two years, personnel of the library checked charge cards for the names of selected students at the close of each day to see whether or not they had withdrawn any books. Close record was kept of the Dewey number of each book withdrawn. A 20 per cent random sample of the freshman and junior class was selected for study, and data were obtained for the freshmen during both semesters and for juniors during the second semester of the first year of the study. The following year data were obtained during both semesters for these students as sophomores and seniors. As in any longitudinal study there was considerable attrition in the sample. At the end of two years, 41 per cent of the original freshman sample were no longer present, and 23 per cent of the junior sample had left the university for various reasons, including completion of course work.

The results did not reveal extensive use of the library by undergraduates, at least insofar as the general collection was concerned. In fact, the majority of men students in the sample withdrew no books from the library's general collection in any given semester during the period covered by the survey. Table 1 shows these results. It is perhaps comforting to note that the percentage of undergraduates withdrawing no books

\footnotetext{
s Gorham Lane, "A Summary Report on The Use of the University Library: The Withdrawal Habits of Undergraduates." University of Delaware, November 15,1963 , p. 15.
} 
TABLE 1

Percentage of the Sample Who Withdrew No Books During the Survey

\begin{tabular}{|c|c|c|c|c|c|c|c|c|}
\hline \multirow[b]{2}{*}{ Crass } & \multirow[b]{2}{*}{ YeAR } & \multirow[b]{2}{*}{ SEMEster } & \multicolumn{2}{|c|}{ MEN } & \multicolumn{2}{|c|}{ WOMEN } & \multicolumn{2}{|c|}{ Total. } \\
\hline & & & No. & Per Cent & No. & Per Cent & No: & Per Cent \\
\hline \multirow[t]{2}{*}{ Class of 1965} & Freshman & $\begin{array}{l}\text { First } \\
\text { Second }\end{array}$ & $\begin{array}{l}84 \\
56\end{array}$ & $\begin{array}{l}73 \\
55\end{array}$ & $\begin{array}{l}64 \\
50\end{array}$ & $\begin{array}{l}71 \\
63\end{array}$ & $\begin{array}{l}148 \\
106\end{array}$ & $\begin{array}{l}72 \\
59\end{array}$ \\
\hline & Sophomore & $\begin{array}{l}\text { First } \\
\text { Second }\end{array}$ & $\begin{array}{l}54 \\
47\end{array}$ & $\begin{array}{l}68 \\
67\end{array}$ & $\begin{array}{l}38 \\
26\end{array}$ & $\begin{array}{l}58 \\
43\end{array}$ & $\begin{array}{l}92 \\
73\end{array}$ & $\begin{array}{l}63 \\
56\end{array}$ \\
\hline \multirow[t]{2}{*}{ Class of 1963} & Junior & Second & 47 & 55 & 17 & 40 & 64 & 50 \\
\hline & Senior & $\begin{array}{l}\text { First } \\
\text { Second }\end{array}$ & $\begin{array}{l}41 \\
39\end{array}$ & $\begin{array}{l}54 \\
59\end{array}$ & $\begin{array}{l}13 \\
10\end{array}$ & $\begin{array}{l}36 \\
30\end{array}$ & $\begin{array}{l}54 \\
49\end{array}$ & $\begin{array}{l}48 \\
49\end{array}$ \\
\hline
\end{tabular}

decreased somewhat from the freshman year through the senior year.

The students in the survey were separated into two groups: those who had withdrawn no books during any semester in the period covered by the survey, and those who had withdrawn at least one. In the latter group the average number of books withdrawn was not large. During the freshman year the average was between three and four, during the sophomore year between six and seven, during the junior year between eight and nine, and during the senior year between six and seven. The increase in the number of books withdrawn by upperclassmen was much more notable for women students than for men students. As second semester seniors, women students' book withdrawals were at their peak (six to seven books), whereas the comparable number for men was one to two books, a figure quite typical of the men's withdrawals when freshmen and sophomores.

When an analysis was made, semester by semester, of book withdrawals by students who remained in the university, their withdrawals were shown to be generally heavier than those of students who were dropped or left the university for various reasons. The differences, however, were small and not statistically significant. Correlational relationships between scholastic standing in high school, or grade point average in college and the number of books withdrawn also failed to reach statistical significance. ${ }^{4}$

Throughout the two-year period of the study, books in the categories of literature and the social sciences were by far the most frequently withdrawn and constituted almost 50 per cent of all withdrawals. Pamphlets, general works, books on religion, and languages were withdrawn least and comprised less than 8 per cent of the withdrawals. Relative to their total withdrawals, men withdrew four times as many books in the area of pure science as did women, and slightly more than twice as many books in technology. Women withdrew half again as many books in the area of literature as did men.

Class differences in withdrawals show only a few trends and differences. Freshmen withdrew most of their books in the field of literature; in fact, they withdraw more books in this area than did students in any other class. Next in frequency for the freshmen were books in the social sciences. They withdrew somewhat more books in history than did other students, and they withdrew somewhat less frequently in the area of technology. These same students as sophomores withdrew

4 Statistical analyses were made by Carol Pemberton of the University Impact Study staff. 
less than half as many books from the area of history as they had when they were freshmen. Sophomores' withdrawals were more frequently from the classifications of social science and philosophy than were those of any other of the classes. Juniors, as compared with other classes, showed no particular pattern or emphasis in their book withdrawals, although as compared with freshmen and sophomores they withdrew significantly more books in the pure sciences. For seniors, as compared with other classes, the areas of heaviest concentration were in pure science and technology. They tended to withdraw books in the areas of philosophy, religion, and literature somewhat less often than students in the other classes.

Although the area of literature was most heavily used by students in all classes, the number of such books withdrawn decreased quite steadily from the freshman through the senior year, but even during the senior year, students were withdrawing almost 20 per cent of their books from this area. Books in the social sciences were next in frequency of use among all classes.

In general, students majoring in the fields of education, English, history, and political science, and possibly biology and nursing, consistently withdrew more books than students in other major fields. Because very few students in some of the major fields were included in the sample, it was not possible to analyze with any degree of certainty the relationship between voluntary withdrawal of books from the library's general collection and the student's major field of study.

The studies reported above represent, for the University of Delaware, pioneering attempts to assess the undergraduates' use of the library. As first attempts they have their limitations. They have, however, demonstrated that it is possible to assess with some degree of reliability the extent to which students actually make use of library facilities, if one carefully designs questionnaires and selects samples, and if tabulating and statistical help are available and there is a cooperative and interested library staff.

It should not be expected that all of the results of such surveys will be surprising. Some, as for example finding that seniors make more use of library facilities than freshmen, may simply support what has been assumed or hoped. But it is reassuring to find that one's hopes have a basis in fact. Other findings are of interest primarily to the particular library being studied and cannot be generalized to include other institutions. Such findings can be put to immediate use within an institution, if faculty members study the data and realize their implications. That fewer than 30 per cent of the students in any school (and fewer than 40 per cent in any class in any school) were found in the library during a given week, or that the majority of men sampled withdrew no books from the university's general collection during any given semester, are findings that should have direct implications for curriculum and program planning, for counselling and advising, and for giving assignments. So also should finding that the nature of work being done by students in the library differs at different times of the semester.

That a university's general collection is not widely used by undergraduates, and that when it is used such use does not seem to have any significant relationship to academic achievement, suggests that an evaluation of the usefulness of a university library in terms of its general collection alone, would be most inadequate. All of these findings have implications not only for the library staff but for the instructional staff as well.

The finding that few students use the library for recreational reading raises several interesting speculations. Do stu- 
dents read for recreation? If so, what do they mean by recreational reading, where do they get their books, and what kind of reading materials do they use? If they do not read for recreation, is this a reflection of their past experience, the lack of available recreational reading materials in the library, or the exigencies of college life? In an era wherein nonwork time is increasing rapidly, this would seem to be an important area of concern. In a study which compared the activities of a small group of college and noncollege students, matched as high school seniors and then followed for a two-year period, it was shown that the college group spent less time in recreational activities than the noncollege group. However, when asked to state how they best liked to spend a free evening, "reading" was given as the response by 40 to 50 per cent of both groups. ${ }^{5}$ But what do they read?

Some highly tentative answers were provided by another study in which a group of seniors in the class of 1964 at the University of Delaware were presented with a list of thirteen kinds of reading materials. ${ }^{6}$ They were asked first to indicate how many of each of the several kinds of materials they had read (on an unassigned basis) during the past academic year and then to indicate those materials which they considered to be "recreational reading." The sample, which was not a truly random sample,

\footnotetext{
sorham Lane, "A Comparison of the Activities and Interests of Two Groups of College Students and a Non-College Group," December 3, 1963.

- These data are summarized from a larger study of student activities and interests which has not been released at the present time.
}

consisted of 175 men and 336 women. The average number of books read by the men was fourteen; for women it was eleven. For men, novels, science, essays, books on technology, and mysteries were ranked, in order, as the most frequently read. For women, the ranking was novels, poetry, essays, mysteries, and biography. When asked which they considered to be recreational reading, men listed, in order among the top five, novels, mysteries, science fiction, poetry, and biography. Women listed novels, mysteries, poetry, biography, and science fiction. For both groups, books in science, political science, technology, or foreign languages were at the bottom of the list as recreational reading. Such results again are not unexpected but might serve as one basis for determining library purchases if one is to serve students' current interests, or for modification of instructional programs, if students' interests are to be modified.

Finally, with all of their limitations and the occasional specificity of their results, attempts at assessing the students' use of the library focus attention on the library itself and its unique position as a potential educational force. Feedback to the faculty and students, and involvement of them in such assessments cannot help but re-emphasize the importance which the university library may have in the academic community. The interest thus aroused many well stimulate, as it has at the University of Delaware, further studies of the library. With increased knowledge of its actual role, the library certainly can more nearly attain its potential.

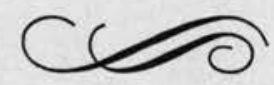

